\title{
Protein Tyrosine Phosphatase 1B Inhibitors from the Root Bark of Pseudolarix amabilis (Nelson) Rehd. (Pinaceae)
}

\section{Zhenggang Yue ${ }^{1,2,3,+}$ Rui Zhou ${ }^{1+}$, Yihan $\mathrm{He}^{1+}{ }^{1_{+}}$, Hongbo Xu${ }^{1}$, Yalei Pan®1, Liyuan Lei® ${ }^{1}$, Pei Xie 1, Zhishu Tang ${ }^{1 *}$ and Jinao Duan 2*}

${ }^{1}$ State Key Laboratory of Research \& Development of Characteristic Qin Medicine Resources (Cultivation), Shaanxi Innovative Drug Research Center, Shaanxi Collaborative Innovation Center of Chinese Medicinal Resource Industrialization, Xianyang, China

${ }^{2}$ Jiangsu Collaborative Innovation Center of Chinese Medicinal Resource Industrialization, Nanjing University of Chinese Medicine, Nanjing, China

${ }^{3}$ Key Laboratory of Tibetan Medicine Research, Chinese Academy of Sciences, Xining, China

(Received December 29, 2018; Revised April 21, 2019; Accepted April 21, 2019)

\begin{abstract}
Pseudolarix amabilis (Nelson) Rehd, is a monotypic genus plant belonging to the family Pinaceae. The root bark, known as "Tu-Jin-Pi" has been used for the treatment of skin diseases. During our activity screening, the water-soluble part of the $70 \% \mathrm{EtOH}$ extract of P. amabilis bark showed excellent inhibitory bioactivities on PTP1B enzyme, leading to the phytochemical isolation of the root bark of $P$. amabilis. Three oleanane-type compounds (1-3) and seven phenolic compounds (4-10) were isolated, in which oleanolic acid 3$O$ - $\beta$-D-glucuronyl-6'-ethyl ester (1) was identified as a new saponin. The chemical structures of these compounds were elucidated by 1D/2D nuclear magnetic resonance and high resolution mass spectra. In addition, their pharmacological inhibitory bioactivities on PTP1B enzyme were evaluated, and the three oleanane-type compounds 1-3 exhibited inhibitory bioactivities with $\mathrm{IC}_{50}$ values of $1.90 \pm 0.37,19.15 \pm 0.10$ and $10.44 \pm 0.59$ $\mu \mathrm{M}$, respectively.
\end{abstract}

Keywords: Pseudolarix amabilis; PTP1B inhibitors; phenolics; oleanolic acid 3-O- $\beta$-D-glucuronyl-6'-ethyl ester. (c) 2019 ACG Publications. All rights reserved.

\section{Introduction}

Protein tyrosine phosphatase 1B (PTP1B) is a master regulator in the insulin and leptin metabolic pathways, which makes it an exciting drug target for type 2 diabetes and obesity [1-4]. In

\footnotetext{
* Corresponding authors: E-Mail: tzs6565@163.com (Tang ZS); dja@ njucm.edu.cn (Duan JA)

$\dagger$ These authors contributed equally to this work.
} 


\section{PTP1B inhibitors from $P$. amabilis}

the insulin metabolic pathway, PTP1B could directly interact with the activated insulin receptor or insulin receptor substrate 1 to dephosphorylate phosphotyrosine residues, thus further reduce insulin sensitivity or shutting down signaling [4]. In the leptin metabolic pathway, PTP1B could negatively regulate leptin signaling through a direct and selective dephosphorylation of the two signaling molecules, JAK2 and STAT3 [5]. Moreover, recent studies indicate that PTP1B overexpression is involved in breast cancer, which suggests that selective PTP1B inhibition might be effective in breast cancer treatment [6-8].

Pseudolarix amabilis (Nelson) Rehd. as a monotypic genus plant, is mainly distributed in southern China. The root bark of P. amabilis, known as "Tu-Jin-Pi" in traditional Chinese medicine, has been widely used for treatment of skin diseases caused by fungal infections in China [9]. Previous phytochemical investigation on this plant revealed a series of characteristic pseudolaric acids[10], such as pseudolaric acids A-B, possessing cytotoxic [11,12] , anti-angiogenic [13,14], anti-microbial [15], and anti-fertility activities [16]; and pseudoferic acids and pseudolarolides, such as pseudoferic acids

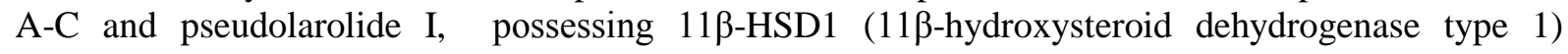
inhibitory activities $[17,18]$. During the course of our search for PTP1B inhibitors from natural sources, $P$. amabilis was investigated. The water-soluble part of the $70 \% \mathrm{EtOH}$ extract of P. amabilis showed excellent inhibitory bioactivities on PTP1B enzyme with $\mathrm{IC}_{50}$ value of $0.52 \pm 0.15 \mu \mathrm{g} / \mathrm{mL}$, thereby, the aqueous constituents of $P$. amabilis were investigated and ten compounds (1-10) were obtained, in which, $\mathbf{1}$ was identified as a new compound and 2-10 were isolated from this plant for the first time. In addition, their bioactivities were tested and the oleanane-type compounds (1-3) exhibited PTP1B enzyme inhibitory activity.

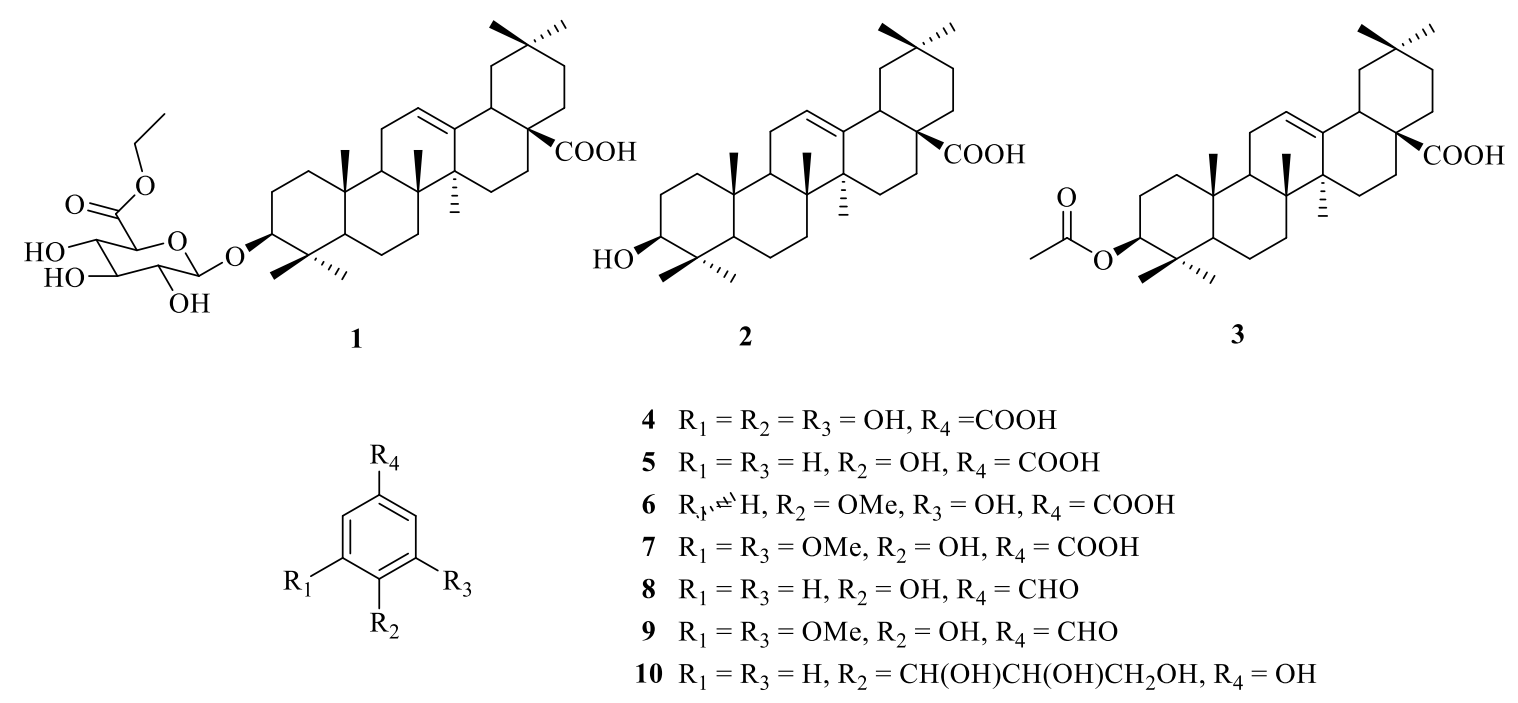

Figure 1. Chemical Structures of compounds 1-10

\section{Materials and Methods}

\subsection{General Procedure}

The ESI-MS was performed on a Quattro Premier instrument (Waters, Miford, MA, USA). The HR-ESI-MS spectra was taken on an Agilent Technologies 6550 Q-TOF. 1D and 2D NMR spectra were recorded on a Bruker-AVANCE 500 instrument (Bruker, Rheinstetten, Germany) with TMS as an internal standard. HP20 gel purchased was from Sunresin New Materials Co. Ltd. (Xi'an, China). MCI gel was purchased from Mitsubishi Chemical Corporation (Tokyo, Japan). C-18 (40 -75 $\mu \mathrm{m})$ silica gel was purchased from SiliCycle Corporation (Quebec, Canada). Toyopearl HW-40F gel $(30-60 \mu \mathrm{m})$ was purchased from TOSOH Corporation (Tokyo, Janapa). Silica gel was purchased from Qingdao Haiyang Chemical Group Corporation (Qingdao, China). 
Yue et.al., Rec. Nat. Prod. (2019) 13:6 475-482

\subsection{Chemicals}

Human recombinant protein tyrosine phosphates 1B (>70\% estimated by SDS-PAG) was purchased from Biomol GmbH (Hamburg, Germany), 4-nitrophenyl phosphate disodium salt solution (p-NPP) and DL-dithiothreitol solution (DTT, $1 \mathrm{M}$ in $\mathrm{H}_{2} \mathrm{O}$ ) ethylene diamine tetraacetic acid (EDTA) were purchased from Sigma Chemical Co. (St. Louis, MO, USA). Other Chemicals were of the highest grade available.

\subsection{Plant Material}

Pseudolarix amabilis (Nelson) Rehd. [also named Larix amabilis Nelson, Pseudolarix kaempferi (Lindl.) Gord. or Larix kaempferi (Lamb.) Carrière] was purchased on October in 2013 from Zhejiang province of China, and authenticated by Prof. Benxiang $\mathrm{Hu}$. A voucher specimen (MPH 20131022) has been deposited in the Medicinal Plants Herbarium (MPH), Shaanxi University of Chinese Medicine, Xianyang, China.

\subsection{Extraction and Isolation}

The procedure of the extraction and isolation of the bark of $P$. amabilis $(10 \mathrm{~kg})$ was provided in supporting information.

\subsection{Oleanolic acid 3-O- $\beta$-D-glucuronyl-6'-ethyl ester (1)}

A white amorphous powder, $[\alpha]_{D}^{20}-10^{\circ}(\mathrm{c} 0.19, \mathrm{MeOH})$; IR (in KBr) $v_{\max }: 3430,2975,2942$, 1699, 1634, 1384, 1204, $1048 \mathrm{~cm}$; ${ }^{1} \mathrm{H}-\mathrm{NMR}\left(500 \mathrm{MHz}, \mathrm{MeOH}-d_{4}\right): \delta_{\mathrm{H}} 5.15$ (brs, H-12), 0.95 (s, H-23), 0.75 (s, H-24), 0.85 (s, H-25), 0.71 (s, H-26), 1.06 (s, H-27), 0.81 (s, H-29), 0.84 (s, H-30), 4.28 (d, J $\left.=7.8 \mathrm{~Hz}, \mathrm{H}-\mathrm{GlcA}-1^{\prime}\right), 4.13\left(\mathrm{t}, J=7.1 \mathrm{~Hz}, \mathrm{CH}_{2} \mathrm{CH}_{3}\right), 1.19\left(\mathrm{q}, J=7.1 \mathrm{~Hz}, \mathrm{CH}_{2} \mathrm{CH}_{3}\right)$ and ${ }^{13} \mathrm{C}-\mathrm{NMR}(125$ $\mathrm{MHz}, \mathrm{MeOH}-d_{4}$ ): $\delta_{\mathrm{C}} 40.0$ (t, C-1), 27.3 (t, C-2), 91.4 (d, C-3), 40.5 (s, C-4), 57.3 (d, C-5), 19.6 (t, C6), 34.3 (t, C-7), 40.9 (s, C-8), 49.0 (d, C-9), 38.2 (s, C-10), 24.8 (t, C-11), 124.0 (d, C-12), 145.5 (s, C-13), 43.2 (s, C-14), 29.2 (t, C-15), 24.4 (t, C-16), 47.9 (s, C-17), 43.1 (d, C-18), 47.6 (t, C-19), 32.0 (s, C-20), 35.2 (t, C-21), 34.1 (t, C-22), 28.8 (q, C-23), 17.2 (q, C-24), 16.2 (q, C-25), 18.0 (q, C-26), 26.7 (q, C-27), 182.1 (s, C-28), 33.9 (q, C-29), 24.3 (q, C-30), 107.4 (d, C-GlcA-1'), 75.6 (d, C-GlcA2'), 77.9 (d, C-GlcA-3'), 73.5 (d, C-GlcA-4'), 77.0 (d, C-GlcA-5'), 171.2 (s, C-GlcA-6'), 62.7 (t, $\mathrm{CH}_{2} \mathrm{CH}_{3}$ ), 14.7 (q, $\mathrm{CH}_{2} \mathrm{CH}_{3}$ ); ESIMS: $m / z 659.3$ [M- H] $]^{-}$, HRESIMS: $m / z 659.4156[\mathrm{M}-\mathrm{H}]^{-}$(calcd. for $\mathrm{C}_{38} \mathrm{H}_{59} \mathrm{O}_{9}, 659.4159$ ). (see supporting information for spectra)

\subsection{PTP1B Inhibition Assay}

All the samples were first dissolved in DMSO and used for the experiment at concentrations of $100^{-1} \mu \mathrm{g} / \mathrm{mL}$ for the crude extract or fractions and $\mu \mathrm{M}$ for pure compounds. The PTP1B enzyme inhibitory activity assay was performed as previously described [22]. p-NPP was used as a substrate to measure enzyme activity. PTP1B $(0.05-0.1 \mu \mathrm{g})$ and $4 \mathrm{mM}$ p-NPP in a buffer containing $50 \mathrm{mM}$ citrate (pH 6.0), $1 \mathrm{mM}$ DTT, $1 \mathrm{mM}$ EDTA (ethylene diamine tetraacetic acid), and $0.1 \mathrm{M} \mathrm{NaCl}$, were added to each of 96-wells having final volume of $100 \mu \mathrm{L}$, with or without test compounds. Incubation was done for $30 \mathrm{~min}$ at $37^{\circ} \mathrm{C}$ and the reaction was terminated using $10 \mathrm{M} \mathrm{NaOH}$. UV absorbance was measured at $405 \mathrm{~nm}$ to estimate the amount of produced p-nitrophenol. Nonenzymatic hydrolysis of pNPP was corrected by measuring the absorbance increase at $405 \mathrm{~nm}$ in the absence of PTP1B enzyme. Each test was duplicated for three times, and the PTP1B inhibitory activity was calculated as: \% inhibition $=\left[1-\left(\mathrm{A}_{\text {test }}-\mathrm{A}_{\text {blank }}\right) /\left(\mathrm{A}_{\text {control }}-\mathrm{A}_{\text {blank }}\right] \times 100\right.$, in which $\mathrm{A}_{\text {control }}$ is the absorbance of the control (DMSO) well, $\mathrm{A}_{\text {test }}$ is the absorbance of the test wells and $\mathrm{A}_{\text {blank }}$ is the absorbance of the enzyme-free wells. 


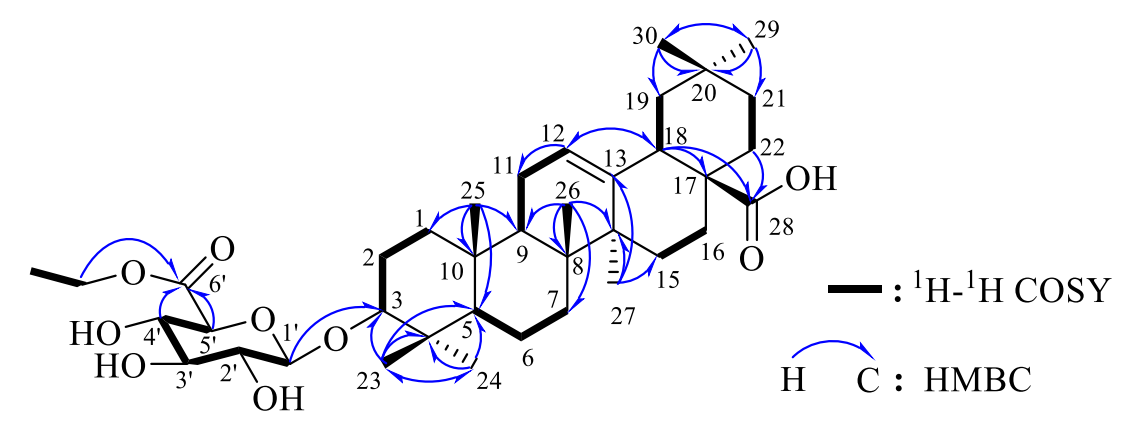

Figure 2. ${ }^{1} \mathrm{H}-{ }^{1} \mathrm{H}$ COSY and key HMBC correlations of compound $\mathbf{1}$

\section{Results and Discussion}

\subsection{Chemistry}

The bark of $P$. amabilis $(10 \mathrm{~kg}$ ) was extracted with $70 \% \mathrm{EtOH}$, evaporated to $1 \mathrm{~L}$, filtrated and applied to a resin HP20 column. The water and $10 \% \mathrm{EtOH}$ fractions were applied to column chromatography using MCI, HW-40 and ODS-C18 gel with a reversed phase system, afforded 10 compounds (Figure 1), including a new saponin (1), and nine known compounds (2-10), identified as oleanolic acid 3-O- $\beta$-D-glucuronyl-6'-ethyl ester (1), oleanolic acid (2) [19], 3 $\beta$-acetyloleanolic acid (3) [19], gallic acid (4), p-benzoic acid (5), isovanillic acid (6), syringic acid (7), $p$ hydroxyphenylglycerol (8) [20], $p$-hydroxybenzaldehyde (9) and syringic aldehyde (10), respectively, by comparing their spectroscopic (MS and NMR) data with Sadtler standard spectra or literature values. Besides, all these known compounds were reported in this plant for the first time.

Compound 1 was obtained as a white amorphous powder and showed positive colorations for Liebermann-Burchard and Molisch test, indicating 1 as a saponin glycoside. Its molecular formula was determined as $\mathrm{C}_{38} \mathrm{H}_{60} \mathrm{O}_{9}$ by HRESIMS $\left(\mathrm{m} / \mathrm{z} 659.4156[\mathrm{M}-\mathrm{H}]^{-}\right.$, calcd 659.4159$)$. The ${ }^{1} \mathrm{H}-\mathrm{NMR}$ spectrum showed seven tertiary methyl protons at $\delta_{\mathrm{H}} 1.06,0.95,0.85,0.84,0.81,0.75$ and 0.71 ; a group of ethyl protons at $4.13\left(2 \mathrm{H}, \mathrm{t}, J=7.1 \mathrm{~Hz}, \mathrm{C}_{2} \mathrm{CH}_{3}\right)$ and $1.19\left(3 \mathrm{H}, \mathrm{q}, J=7.1 \mathrm{~Hz}, \mathrm{CH}_{2} \mathrm{C}_{3}\right)$; an olefinic proton at $5.15(1 \mathrm{H}, \mathrm{br} . \mathrm{s})$; and an anomeric proton at $\delta_{\mathrm{H}} 4.28(1 \mathrm{H}, \mathrm{d}, J=7.8 \mathrm{~Hz})$ indicating the present of a glycosyl as $\beta$ configuration. The ${ }^{13} \mathrm{C}-\mathrm{NMR}$ and DEPT spectra displayed 38 carbon resonances as $8 \times \mathrm{CH}_{3}, 11 \times \mathrm{CH}_{2}, 10 \times \mathrm{CH}$ and $9 \times \mathrm{C}, 30$ of which belonged to the aglycone carbons, while the remaining signals were assignable to a glucuronosyl moiety $\left[\delta_{\mathrm{C}} 107.4,75.6,77.9,73.5,77.0\right.$ and 171.2] and an ethyl moiety $\left[\delta_{\mathrm{C}} 62.7\left(\mathrm{CH}_{2} \mathrm{CH}_{3}\right)\right.$ and $\left.14.7\left(\mathrm{CH}_{2} \mathrm{CH}_{3}\right)\right]$. Among the carbon resonances of the aglycone, $\delta_{\mathrm{C}} 33.9,28.8,26.7,24.3,18.0,17.2$ and 16.2 were due to seven tertiary methyl; $\delta_{\mathrm{C}}$ 124.0 and 145.5 were due to two olefinic carbons; $\delta_{\mathrm{C}} 182.1$ were due to a carbonyl carbon. These resonances along with the proton signals indicated that the aglycone of $\mathbf{1}$ possessed an oleanolic acid (2) skeleton.

Moreover, the assignments of the NMR signals were derived from ${ }^{1} \mathrm{H}-{ }^{1} \mathrm{H}$ COSY, HSQC and HMBC experiments (Figure 2 and Table 1). In the HMBC spectrum, correlation of $\mathrm{H}-1^{\prime}$ to $\mathrm{C}-3$ disclosed that the glucuronosyl unit was linked at C-3 of the aglycone; correlation of the methane protons of $\mathrm{CH}_{2} \mathrm{CH}_{3}$ to the carbonyl carbon of glucuronosyl unit revealed that the ethyl unit was linked at $\mathrm{C}-6^{\prime}$. Therefore, compound 1 was elucidated as oleanolic acid 3-O- $\beta$-D-glucuronyl- $6^{\prime}$-ethyl ester. Compared with the compound oleanolic acid 3-O- $\beta$-D-glucuronyl-6'-methyl ester (1a) of the reference [21], all data were almost consistent. In addition, for $\mathbf{1}$ was a glucuronide derivative and ethanol solvent was used during the extraction process, oleanolic acid 3-O- $\beta$-D-glucuronic acid was purchased and refluxed according to the extraction protocol of the plant materials and no traget product was detected by TLC, so $\mathbf{1}$ was confrimed as a natural product in P. amabilis. 
Yue et.al., Rec. Nat. Prod. (2019) 13:6 475-482

Table 1. ${ }^{1} \mathrm{H}$ and ${ }^{13} \mathrm{C}-\mathrm{NMR}$ data for $\mathbf{1}, \mathbf{1 a}$ and $\mathbf{2}$

\begin{tabular}{|c|c|c|c|c|c|c|}
\hline \multirow{2}{*}{ No. } & \multicolumn{2}{|r|}{1} & \multicolumn{2}{|r|}{$\mathbf{1 a}^{[21]}$} & \multicolumn{2}{|r|}{2} \\
\hline & $\delta_{\mathrm{C}}{ }^{\mathrm{a}}$ & $\delta_{\mathrm{H}}^{\mathrm{b}}$ & $\delta_{\mathrm{C}}{ }^{\mathrm{c}}$ & $\delta_{\mathrm{H}}{ }^{\mathrm{d}}$ & $\delta_{\mathrm{C}}^{\mathrm{a}}$ & $\delta_{\mathrm{H}}^{\mathrm{b}}$ \\
\hline 1 & $40.0(\mathrm{t})$ & $\begin{array}{l}0.97(\mathrm{H}-1 \mathrm{a}, c a) \\
1.60(\mathrm{H}-1 \mathrm{~b}, c a)\end{array}$ & 38.7 & & 40.2 & \\
\hline 2 & $27.3(\mathrm{t})$ & $\begin{array}{l}1.65(\mathrm{H}-2 \mathrm{a}, c a .) \\
1.81(\mathrm{H}-2 \mathrm{~b}, c a .)\end{array}$ & 26.5 & & 28.2 & \\
\hline 3 & 91.4 (d) & $3.15(\mathrm{dd}, 11.7,4.4)$ & 89.1 & $3.38(\mathrm{dd}, 12,4)$ & 80.1 & $3.20(\mathrm{dd}, 11.7,4.9)$ \\
\hline 4 & $40.5(\mathrm{~s})$ & - & 39.5 & & 40.8 & \\
\hline 5 & $57.3(\mathrm{~d})$ & $0.70(\mathrm{~d}, 12.0)$ & 55.8 & & 57.1 & \\
\hline 6 & $19.6(\mathrm{t})$ & $\begin{array}{l}1.57(\mathrm{H}-6 \mathrm{a}, c a .) \\
1.40(\mathrm{H}-6 \mathrm{~b}, c a .)\end{array}$ & 18.5 & & 19.8 & \\
\hline 7 & $34.3(\mathrm{t})$ & $1.30(c a)$. & 33.2 & & 34.4 & \\
\hline 8 & $40.9(\mathrm{~s})$ & - & 39.7 & & 40.9 & \\
\hline 9 & 49.0 (d) & $1.58(c a)$. & 48.0 & & 49.5 & \\
\hline 10 & $38.2(\mathrm{~s})$ & - & 37.0 & & 37.2 & \\
\hline 11 & $24.8(\mathrm{t})$ & 1.89 (ca.) & 23.8 & & 24.4 & \\
\hline 12 & $124.0(d)$ & 5.15 (br.s) & 122.6 & $5.48(\mathrm{t}, 2.5)$ & 124.0 & $5.25(1 \mathrm{H}, \mathrm{br} . \mathrm{s})$ \\
\hline 13 & $145.5(\mathrm{~s})$ & - & 144.9 & & 145.5 & \\
\hline 14 & $43.2(\mathrm{~s})$ & - & 42.0 & & 43.5 & \\
\hline 15 & $29.2(\mathrm{t})$ & $\begin{array}{l}1.07(\mathrm{H}-15 \mathrm{a}, c a .) \\
1.78(\mathrm{H}-15 \mathrm{~b}, c a .)\end{array}$ & 28.3 & & 29.2 & \\
\hline 16 & $24.4(\mathrm{t})$ & $\begin{array}{l}1.60(\mathrm{H}-16 \mathrm{a}, c a .) \\
2.00(\mathrm{H}-16 \mathrm{~b}, c a .)\end{array}$ & 23.7 & & 24.8 & \\
\hline 17 & 47.9 (s) & $\overline{(125)}$ & 46.7 & & 48.8 & \\
\hline 18 & $43.1(\mathrm{~d})$ & $2.82(\mathrm{dd}, 13.5,4.2)$ & 42.2 & $3.29(\mathrm{dd}, 10,2)$ & 43.1 & $2.80(\mathrm{dd}, 13.2,4.2)$ \\
\hline 19 & $47.6(t)$ & $\begin{array}{l}1.13(\mathrm{H}-19 \mathrm{a}, c a .) \\
1.58(\mathrm{H}-19 \mathrm{~b}, c a .)\end{array}$ & 46.5 & & 47.6 & \\
\hline 20 & $32.0(\mathrm{~s})$ & - & 31.0 & & 30.7 & \\
\hline 21 & $35.2(\mathrm{t})$ & $\begin{array}{l}1.20(\mathrm{H}-21 \mathrm{a}, c a .) \\
1.41(\mathrm{H}-21 \mathrm{~b}, c a .)\end{array}$ & 34.3 & & 35.2 & \\
\hline 22 & $34.1(t)$ & $\begin{array}{l}1.54 \text { (H-21a, ca.) } \\
1.76(\mathrm{H}-21 \mathrm{~b}, \mathrm{ca} .)\end{array}$ & 33.3 & & 34.1 & \\
\hline 23 & $28.8(\mathrm{q})$ & $0.95(\mathrm{~s})$ & 28.2 & $1.31(\mathrm{~s})$ & 29.2 & $0.97(\mathrm{~s})$ \\
\hline 24 & $17.2(q)$ & $0.75(\mathrm{~s})$ & 16.9 & $0.97(\mathrm{~s})$ & 16.6 & $0.75(\mathrm{~s})$ \\
\hline 25 & $16.2(q)$ & $0.85(\mathrm{~s})$ & 15.5 & $1.02(\mathrm{~s})$ & 16.2 & $0.91(\mathrm{~s})$ \\
\hline 26 & $18.0(\mathrm{q})$ & $0.71(\mathrm{~s})$ & 17.4 & $0.82(\mathrm{~s})$ & 18.0 & $0.72(\mathrm{~s})$ \\
\hline 27 & 26.7 (q) & $1.06(\mathrm{~s})$ & 26.2 & $1.31(\mathrm{~s})$ & 26.7 & $1.11(\mathrm{~s})$ \\
\hline 28 & $182.1(\mathrm{~s})$ & - & 180.1 & & 182.1 & \\
\hline 29 & 33.9 (q) & $0.81(\mathrm{~s})$ & 33.2 & $0.96(\mathrm{~s})$ & 33.8 & $0.88(\mathrm{~s})$ \\
\hline 30 & $24.3(\mathrm{q})$ & $0.84(\mathrm{~s})$ & 23.8 & $0.99(\mathrm{~s})$ & 24.3 & $0.89(\mathrm{~s})$ \\
\hline GlcA-1' & $107.4(d)$ & $4.28(\mathrm{~d}, 7.8)$ & 107.3 & $4.98(\mathrm{~d}, 8)$ & & \\
\hline $2^{\prime}$ & $75.6(d)$ & 3.24 (ca.) & 75.4 & $4.07(\mathrm{t}, 8.5)$ & & \\
\hline $3^{\prime}$ & 77.9 (d) & 3.36 (са.) & 78.0 & $4.25(\mathrm{t}, 9)$ & & \\
\hline $4^{\prime}$ & 73.5 (d) & 3.53 (са.) & 73.1 & $4.46(\mathrm{t}, 9)$ & & \\
\hline $5^{\prime}$ & 77.0 (d) & 3.79 (са.) & 77.2 & $4.58(\mathrm{~d}, 9.5)$ & & \\
\hline $6^{\prime}$ & $171.2(\mathrm{~s})$ & - & 170.8 & & & \\
\hline$\underline{\mathrm{CH}_{2}} \mathrm{CH}_{3}$ & $62.7(\mathrm{t})$ & $4.13(t, 7.1)$ & & & & \\
\hline $\mathrm{CH}_{2} \underline{\mathrm{CH}_{3}}$ & 14.7 (q) & $1.19(\mathrm{q}, 7.1)$ & & & & \\
\hline $\mathrm{CH}_{3}$ & & & 52.0 & $3.73(\mathrm{~s})$ & & \\
\hline
\end{tabular}

${ }^{\text {a }}{ }^{13} \mathrm{C}-\mathrm{NMR}$ at $125 \mathrm{MHz}, \delta$ in $\mathrm{MeOH}-d_{4}$, in ppm from TMS.

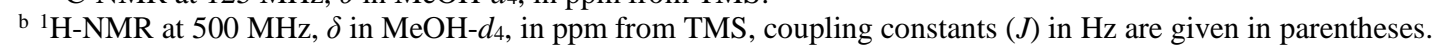

${ }^{\text {c }}{ }^{13} \mathrm{C}-\mathrm{NMR}$ at $125 \mathrm{MHz}, \delta$ in pyridine- $d_{5}$.

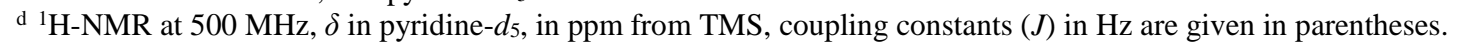




\subsection{Biological Assay}

The inhibitory activity on PTP1B enzyme was evaluated using pNPP as a substrate, and oleanolic acid (2) as a known PTP1B inhibitor was used as a positive control[23]. In our early research for PTP1B inhibitors from natural sources, the extract of $P$. amabilis demonstrated potent activity with IC50 value of $0.56 \pm 0.06 \mu \mathrm{g} / \mathrm{mL}$, furthermore, the water-soluble fraction of the extract showed stronger inhibitory activity than the precipitate fraction with $\mathrm{IC}_{50}$ value of $0.52 \pm 0.15$ and $1.15 \pm 0.06$ $\mu \mathrm{g} / \mathrm{mL}$, respectively (Table 2). These results showed $P$. amabilis had a promising prospect of new application for the treatment of type 2 diabetes and led the isolation of the aqueous constituents of $P$. amabilis.

As shown in Table 3, the ten isolated compounds were tested on PTP1B enzyme, and only oleanane-type compounds (1-3) exhibited PTP1B inhibition with $\mathrm{IC}_{50}$ values of $1.90 \pm 0.37,19.15 \pm$ 0.10 and $10.44 \pm 0.59 \mu \mathrm{M}$, respectively. By comparison of the structure activity relationships (SARs), we found that oleanolic acid skeleton was the critical structural part for PTP1B inhibitory bioactivity. In addition, the substitute at C-3 of the oleanane-type compounds may alter their activity, especially, when it was $\beta$-D-glucuronyl-6'-ethyl ester, compound 1 showed strong PTP1B inhibitory bioactivity.

Moreover, for the activities of the isolated compounds are less than the active sites, it prompts that there maybe more potent active trace compounds in $P$. amabilis, which should be explored in future.

Table 2. Inhibitory activity of extacts against PTP1B

\begin{tabular}{lc}
\hline The bark of $\boldsymbol{P}$. amabilis & $\mathbf{I C}_{\mathbf{5 0}}(\boldsymbol{\mu \mathbf { g }} / \mathbf{m L})$ \\
\hline 70\%EtOH extract & $0.56 \pm 0.06$ \\
The water-soluble fraction of 70\%EtOH extract & $0.52 \pm 0.15$ \\
The precipitate fraction of $70 \%$ EtOH extract & $1.15 \pm 0.06$ \\
\hline
\end{tabular}

Table 3. Inhibitory activity of compounds $\mathbf{1 - 1 0}$ against PTP1B

\begin{tabular}{ccc}
\hline Compd. & Inhibition rate $(\%$, at $\mathbf{2 0} \boldsymbol{\mu g} / \mathbf{m L})$ & $\mathbf{I C}_{\mathbf{5 0}}(\boldsymbol{\mu M})$ \\
\hline $\mathbf{1}$ & $93.49 \pm 1.24$ & $1.90 \pm 0.37$ \\
$\mathbf{2}$ & $50.70 \pm 3.50$ & $19.15 \pm 0.10$ \\
$\mathbf{3}$ & $86.47 \pm 4.61$ & $10.44 \pm 0.59$ \\
$\mathbf{4 - 1 0}$ & NA & - \\
\hline
\end{tabular}

\section{Acknowledgments}

This project was financially supported by the National Natural Sciences Foundation of China (No. 81503237), the Natural Science Foundation of Shaanxi (grant No. 2016JQ8030), the Key R\&D Program of Shaanxi Province (No. 2015SF073, 2017SF360), the Open Projects Program of the Key Laboratory of Tibetan Medicine Research, Chinese Academy of Sciences (No. 2014-TMR-01), the Innovative Research Team in TCM Material Foundation and Key Preparation Technology (No. 2012KCT-20), and the Innovation Projects of Science and Technology in Shaanxi Province (No. 2013KTCQ03-14)

\section{Supporting Information}

Supporting information accompanies this paper on http://www.acgpubs.org/journal/records-ofnatural-products

\section{ORCID}

Zhenggang Yue: 0000-0001-6296-8509

Rui Zhou: 0000-0002-3069-8089

Yihan He: 0000-0001-9772-6921 
Yue et.al., Rec. Nat. Prod. (2019) 13:6 475-482

Hongbo Xu: 0000-0001-9633-5566

Yalei Pan: 0000-0002-3579-4395

Liyan Lei: 0000-0001-8141-4042

Pei Xie: 0000-0002-1799-6217

Zhishu Tang: 0000-0001-7795-9322

Jinao Duan: 0000-0002-7657-0013

\section{References}

[1] Z. Zhang, G. Dodd and T. Tiganis (2015). Protein tyrosine phosphatases in hypothalamic insulin and leptin signaling, Trends. Pharmacol. Sci. 36, 661-674.

[2] J. Bakke and F. Haj (2015). Protein-tyrosine phosphatase 1B substrates and metabolic regulation, Semin. Cell. Dev. Biol. 37, 58-65.

[3] E. Panzhinskiy, J. Ren and S. Nair (2013). Pharmacological inhibition of protein tyrosine phosphatase 1B: a promising strategy for the treatment of obesity and type 2 diabetes mellitus, Curr. Med. Chem. 20 , 2609-2625.

[4] S. Zhang and Z. Zhang (2007). PTP1B as a drug target: recent developments in PTP1B inhibitor discovery, Drug. Discov. Today 12,373-381.

[5] I. Lund, J. Hansen, H. Andersen, N. Moller and N. Billestrup (2005). Mechanism of protein tyrosine phosphatase 1B-mediated inhibition of leptin signaling, J. Mol. Endocrinol. 34, 339-351.

[6] R. He, Z. Yu, R. Zhang and Z. Zhang (2014). Protein tyrosine phosphatases as potential therapeutic targets, Acta. Pharmacol. Sin. 35, 1227-1246.

[7] S. Yip, S. Saha and J. Chernoff (2010). PTP1B: a double agent in metabolism and oncogenesis, Trends. Biochem. Sci. 35, 442-449.

[8] N. Tonks and S. Muthuswamy (2007). A brake becomes an accelerator: PTP1B-a new therapeutic target for breast cancer, Cancer Cell 11, 214-216.

[9] S. Wu, R. Hu and G. Yang (1960). Experimental, clinical and pharmacological study on the antifungal effects of Pesudolarix kaempferi Gord., Chin. J. Dermatol. 8, 18-25.

[10] P. Chiu, L. Leung and B. Ko (2010). Pseudolaric acids: isolation, bioactivity and synthetic studies, Nat. Prod. Rep. 27, 1066-1083.

[11] G. Chen, Z. Li, D. Pan, C. Tang, X. He, G. Xu, K. Chen and K. Lee (1993). The isolation and structural elucidation of four novel triterpene lactones, pseudolarolides A, B, C, and D, from Pseudolarix kaempferi, J. Nat. Prod. 56, 1114-1122.

[12] P. Liu, H. Guo, W. Wang, J. Zhang, N. Li, J. Han, J. Zhou, Y. Hu, T. Zhang, Z. Liu and D. Guo (2007). Cytotoxic diterpenoids from the bark of Pseudolarix kaempferi and their structure-activity relationships, J. Nat. Prod. 70, 533-537.

[13] S. Yang, Y. Cai, B. Zhang, L. Tong, H. Xie, Y. Wu, L. Lin, J. Ding and J. Yue (2008). Structural modification of an angiogenesis inhibitor discovered from traditional Chinese medicine and a structureactivity relationship study, $\mathrm{J}$. Med. Chem. 51, 77-85.

[14] Y. Tong, X. Zhang, M. Geng, J. Yue, X. Xin, F. Tian, X. Shen, L. Tong, M. Li, C. Zhang, W. Li, L. Lin, J. Ding (2006). Pseudolarix acid B, a new tubulin-binding agent, inhibits angiogenesis by interacting with a novel binding site on tubulin, Mol. Pharmacol. 69, 1226-1233.

[15] S. Yang, L. Dong, Y. Wang, Y. Wu and J. Yue (2003). Antifungal diterpenoids of Pseudolarix kaempferi, and their structure-activity relationship study, Bioorg. Med. Chem. 11, 4577-4584.

[16] Y. Zhang, R. Lu and A. Yan (1990). Inhibition of ova fertilizability by pseudolaric acid B in hamster, Acta. Pharmacol. Sin. 11, 60-62.

[17] X. Wu, J. He, Y. Shen, L. Dong, Z. Pan, G. Xu, X. Gong, L. Song, Y. Leng, Y. Li, L. Peng and Q. Zhao (2012). Pseudoferic acids A-C, three novel triterpenoids from the root bark of Pseudolarix kaempferi, Tetrahedron. Lett. 53, 800-803.

[18] H. Guo, S. Yao, X. Yang, Y. Chen, F. Gong, J. Tong, J. Qian, A. Zhang and X. Cai (2018). Oxidatively rearranged cycloartane triterpenoids from the seeds of Pseudolarix amabilis, Nat. Prod. Res. 32, 18171823.

[19] H. Zhou, F. Wang and Z. Fang (2011). Study on triterpenes from Solanum torvum, China. J. Chin. Materia. Med. 36, 2096-2098.

[20] J. Krauss and D. Unterreitmeier (2002). Synthesis and antimicrobial activity of hydroxyalkyl- and hydroxyacyl-phenols and their benzyl ethers, Arch. Pharm. 335, 94-98. 
[21] F. Melek, T. Miyase, O. El-Gindi, S. Abdel-Khalik and M. Haggag (1996). Saponins from Fagonia mollis, Phytochemistry 42, 1405-1407.

[22] L. Cui, M. Na, H. Oh, E. Bae, D. Jeong, S. Ryu, S. Kim, B. Kim, W. Oh and J. Ahn (2006). Protein tyrosine phosphatase 1B inhibitors from Morus root bark, Bioorg. Med. Chem. Lett. 16, 1426-1429.

[23] C. Liu, T. Guo, L. Zhang, Y. Yue, P. Wang, F. Yang, X. Li (2013). Synthesis and biological evaluation of oleanolic acid derivatives as PTP1B inhibitors, Eur. J. Med. Chem. 63, 511-522.

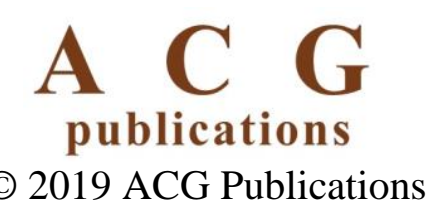

